\title{
ANALISIS KINERJA KEUANGAN PT. INDORIS PRINTINGDO BERSUMBER PADA KEPUTUSAN MENTERI BUMN NOMOR: KEP-100/MBU/2002
}

\author{
Wardokhi \\ Fakultas Ekonomi, Universitas Pamulang \\ dosen02165@unpam.ac.id
}

\begin{abstract}
This reseaarch aims to determine the financial performance of PT. Indoris Printingdo, based on the Decree of the Minister of BUMN no. 100 / MBU / 2002 on Rating of State-Owned Enterprise Health Level during the period of 2013 - 2015. Data collection methods in this study is obtained by quoting directly from the financial statements in PT. Indoris Printingdo from 2013 to 2015. The analysis technique in this research is quantitative descriptive analysis. The data analysis used is based on the Decree of the Minister of BUMN no:100 / MBU / 2002.Based on the results of research known that the financial performance of PT. Indoris Printingdo based on Decree of the Minister of BUMN no.100 / MBU / 2002 is in 2013 to get the title of "HEALTHY A", in 2014 get the title "UNWELL BBB" and in 2015 the company get the title "HEALTHY AA". This shows the financial performance of PT. Indoris Printingdo is still in good category or experiencing increasing trend.
\end{abstract}

Keywords : Financial performance and healthy level.

\section{PENDAHULUAN}

Untuk membantu mengetahui tingkat kinerja keuangan suatu perusahaan, apakah dalam kondisi baik atau buruk maka yang digunakan adalah Analisis Laporan Keuangan perusahaan tersebut . Alat analisis yang yang dipergunakan untuk menunjang penafsiran suatu laporan keuangan perusahaan sehingga menghasilkan keputusan, diantaranya adalah menggunakan Rasio.

Rasio Keuangan atau Financial Ratio yang digunakan adalah rasio likuiditas, rasio profitabilitas, rasio solvabilitas dan rasio aktifitas. Perusahaan memerlukan alat ukur rasio keuangan untuk menilai kinerja keuangannya dengan menggunakan perbandingan data laporan keuangan yang terdapat pada pos - pos laporan keuangannya, yaitu pada laporan posisi keuangan, laporan laba/rugi, laporan arus kas dan laporan perubahan modal.

Perusahaan yang bergerak pada sektor industri dasar dan kimia, yang memproduksi berbagai macam produk plastik dan kemasan adalah salah satu sektor yang dibutuhkan untuk kehidupan manusia. Perusahaan manufaktur 
dalam memproduksi produknya mulai dari bahan mentah seperti dasar kimia, plastik hingga menjadi barang jadi yang ditujukan untuk kebutuhan manusia. Serta dapat memberikan keuntungan yang lebih dalam kehidupan yang dikarenakan berbahan ringan, praktis, ekonomis dan dapat didaur ulang kembali serta tahan terhadap pengaruh lingkungan sehingga produk kemasan dan plastik dapat digunakan untuk bahan - bahan lain yang tidak tahan lama.

Menurut Hengky Wibawa, Eksekutive Direktur Federasi Pengemasan Indonesia (Indonesia Packaging Federation/APF), bahwa dalam lima tahun terakhir industri packaging atau kemasan di Indonesia masih tercatat bertumbuh, tapi target pertumbuhan $10 \%$ belum dapat dicapai dan diprediksi antara 8-9\%. Berdasarkan penjelasnnya juga, selama tahun 2014 penjualan produk kemasan meningkat menjadi 7\% yaitu Rp. 70 Triliun dari penjualan 2013. Hengky menyimpulkan bahwa nilai tersebut sebagian besar ditopang oleh penjualan dari segmen produk kemasan plastik yaitu mencapai 60\%, produk kemasan karton hanya $27 \%$ dan sisanya dari segmen produk kemasan kaleng dan gelas. Serapan domestik mendominasi lebih dari $90 \%$. Sedangkan serapan ekspor kurang lebih hanya 10\%. Selanjutnya kontribusi terbesar lainnya adalah kemasan dengan material paperboard (29\%), rigid plastic (15\%), metal cans atau kaleng logam (4\%), Woven Bag atau tas anyaman (4\%) serta glass contain atau berbahan gelas (3\%).

Penelitian ini diharapkan dapat memberikan value tentang hal apa saja yang masih harus diperbaiki dan ditingkatkan terutama kinerja keuangannya, menemukan masalah perusahaan dari aspek keuangan yang selanjutnya dapat memberikan solusi agar perusahaan tetap dalam kondisi sehat dengan standar kesehatan menurut Keputusan Menteri BUMN Nomer: 100/MBU/2002. Penelitian ini bertujuan untuk menganalisa kinerja keuangan di PT. Indoris Printingdo yang berlokasi di Cikupa Tangerang Banten, Indonesia.

PT. Indoris Printingdo Indonesia merupakan perusahaan yang bergerak dalam industri kemasan, baik yang berupa kemasan cetak offset, kemasan karton gelombang maupun kombinasi dari keduanya. Untuk dapat mengetahui kesehatan perusahaan, PT. Indoris Printingdo Indonesia perlu melakukan 
penilaiaan kinerja sehingga mampu membuat perencanaan dan strategi dalam menghadapi persaingan bisnis yang pesat. Kinerja sebagai hasil atau tingkat keberhasilan suatu organisasi atau perusahaan selama periode tertentu didalam melaksanakan bisnis, yang dibandingkan dengan berbagai kemungkinan seperti sasaran stratejiknya, ukuran kinerjanya, target kinerja dan inisiatif stratejik yang telah ditentukan terlebih dahulu.

Berdasarkan uraian diatas, menarik untuk diteliti bagaimana penilaian tingkat kesehatan atau keberhasilan kinerja PT. Indoris Printingdo jika diukur dengan standar KEPMEN BUMN Nomer: 100/MBU/2002. Sehingga peneliti tertarik melakukan penelitian dengan judul "Analisis Kinerja Keuangan PT. Indoris Printingdo Bersumber Pada Keputusan Menteri BUMN Nomor: KEP-100/MBU/2002".

\section{TELAAH LITERATUR DAN PENGEMBANGAN HIPOTESIS}

\section{Pengertian Manajemen}

Menurut Robbins dan Coulter (2008:36) "Manajemen adalah mengkoordinasi dan mengawasi kegiatan orang lain sehingga kegiatan mereka selesai dengan efisien dan efektif'. Menurut Bateman dan Snell (2008:14) "Manajemen adalah proses dalam bekerja dengan orang - orang dan berbagai sumberdaya untuk mencapai tujuan organisasi”.

Sedangkan menurut Andry Feriyanto dan Endang Shyta Triana (2015:4) "manajemen berasal dari kata to manage yang berarti mengatur (mengelola)". Jadi dari pendapat para ahli, dapat disimpulkan bahwa manajemen adalah bagaimana mengatur seluruh sumberdaya yang dimiliki oleh perusahaan atau organisasi secara efektif dan efisien sehingga dapat tercapai tujuan perusahaan atau organisasi.

\section{Pengertian Manajemen Keuangan}

Terdapat beberapa pendapat para ahli yang mendefinisikan pengertian manajemen keuangan yaitu diantaranya adalah: 
a. Menurut Bambang Riyanto (2001:4), dalam bukunya Dasar - Dasar Pembelanjaan Perusahaan, menerangkan bahwa:

"Manajemen keuangan adalah manajemen untuk fungsi - fungsi pembelanjaan"

b. Dalam buku Financial Management, oleh Arthur J. Keown, Jhon D. Martin, J. Wiliam Patty dan David F. Scott, Jr (2005:4), , menerangkan bahwa:

"Financial Management is corcerned with the maintenance and creation of economic value or wealth".

Artinya, "Manajemen Keuangan adalah mengenai pemeliharaan dan penciptaan dari nilai ekonomi atau kekayaan"

c. Irham Fahmi (2012:02) menjelaskan bahwa: "Manajemen keuangan merupakan penggabungan dari ilmu dan seni yang membahas, mengkaji dan menganalisis tentang bagaimana seorang manajer keuangan dengan dengan mempergunakan seluruh sumber daya perusahaan untuk mencari dana, mengelola dana dan membagi dana dengan tujuan mampu memberikan profit atau kemakmuran bagi para pemegang saham dan sustainability (berkelanjutan) usaha bagi perusahaan".

Berdasarkan pendapat para ahli tersebut dapat disimpulkan bahwa manajemen keuangan adalah suatu usaha dalam menyediakan, mengelola dan mendistribusikan sumber dana, dimana dengan dana tersebut perusahaan dapat memperoleh atau mendapatkan aktiva.

\section{Definisi Laporan Keuangan}

Laporan keuangan merupakan hasil akhir dari proses pencatatan transaksi keuangan dalam perusahaan atau organisasi. Penyusunan laporan keuangan adalah bertujuan untuk menyediakan informasi keuangan perusahaan atau organisasi kepada pihak - pihak yang berkepentingan. Laporan keuangan adalah meliputi laporan laba rugi, laporan perubahan modal, laporan posisi keuangan, laporan arus kas dan catatan atas laporan keuangan. 
Irham Fahmi (2013:21) menerangkan bahwa "laporan keuangan merupakan suatu informasi yang menggambarkan kondisi keuangan suatu perusahaan dan lebih jauh informasi tersebut dapat dijadikan sebagai gambaran kinerja keuangan perusahaan tersebut".

Sedangkan menurut Munawir (2013:21) "laporan keuangan merupakan alat yang sangat penting untuk memperoleh informasi sehubungan dengan posisi keuangan dan hasil - hasil yang telah dicapai oleh perusahaan yang bersangkutan".

Berdasarkan pengertian dari para ahli, maka dapat disimpulkan bahwa laporan keuangan adalah suatu laporan yang dihasilkan dari proses akuntansi untuk memberikan gambaran tentang kondisi keuangan suatu perusahaan atau organisasi sehingga dapat dijadikan alat untuk mengukur kinerja keuangan dari kegiatan usaha yang dijalankannya dalam periode tertentu.

\section{Pengertian Manajemen Kinerja}

Menurut Mahmudi (2007:5) "Manajemen Kinerja adalah suatu proses yang sistematik, artinya untuk memperbaiki kinerja diperlukan langkah langkah atau tahap - tahap yang terencana dengan baik".

\section{Definisi Kinerja Perusahaan}

Priansa dan Suwatno (2011:196) mengatakan bahwa "kinerja sebagai hasil yang dicapai seseorang menurut ukuran yang berlaku, dalam kurun waktu tertentu, berkenaan dengan pekerjaan serta perilaku dan tindakannya".

Menurut Suyadi Prawirosentono (2008:2) "kinerja sebagai hasil kerja yang dicapai oleh seseorang atau sekelompok orang dalam suatu organisasi sesuai dengan wewenang dan tanggung jawabnya masing - masing dalam rangka upaya mencapai tujuan organisasi bersangkutan secara legal, tidak melanggar hukum dan sesuai dengan moral maupun etika".

Jadi kesimpulan kinerja perusahaan adalah hasil kerja yang dilakukan oleh perusahaan dengan standar tertentu secara legal sehingga tujuan perusahaan tercapai selama periode tertentu. 


\section{Pengertian Kinerja Keuangan}

Mulyadi (2001:63) mengatakan bahwa "kinerja keuangan perusahaan merupakan suatu tampilan perusahaan dalam periode tertentu. Penilaian kinerja perusahaan adalah penentuan secara periodik, efektifitas operasional suatu organisasi, karyawan berdasarkan sasaran standar dan kinerja yang telah ditetapkan sebelumnya".

Sedangkan menurut Mulyadi (2001:64) "kinerja keuangan perusahaan dapat diukur dari laporan keuangan yang dikeluarkan secara periodik".

\section{Indikator Pengukuran Aspek Keuangan}

Penilaian kinerja pada perusahaan menurut KEPMEN BUMN Nomor: 100/MBU/2002 adalah pada 3 (tiga) aspek yaitu keuangan, operasional dan administrasi. Dalam penilaian aspek keuangan, berikut adalah indikator dan bobotnya :

Tabel 1

Daftar Indikator aspek keuangan dan bobot nya.

\begin{tabular}{|l|c|c|}
\hline \multirow{2}{*}{\multicolumn{1}{|c|}{ Indikator }} & \multicolumn{2}{c|}{ Bobot } \\
\cline { 2 - 3 } & $\begin{array}{c}\text { Infra } \\
\text { Struktur }\end{array}$ & $\begin{array}{c}\text { Non Infra } \\
\text { struktur }\end{array}$ \\
\hline 1. Return On Equity (ROE) & 15 & 20 \\
\hline 2. Return On Investment (ROI) & 10 & 15 \\
\hline 3. Rasio Kas (Cash Ratio) & 3 & 5 \\
\hline 4. Rasio Lancar (Quick Ratio) & 4 & 5 \\
\hline 5. Collection Periode(CP) & 4 & 5 \\
\hline 6. Perputaran Persediaan (PP) & 4 & 5 \\
\hline 7. Perputaran Total Aset (Turn over Ratio) & 4 & 5 \\
\hline $\begin{array}{l}\text { 8. Rasio Modal Sendiri terhadap total Aktiva (Ratio Of } \\
\text { Owner's Equity to Total Assets) }\end{array}$ & 6 & 10 \\
\hline Total Bobot & $\mathbf{5 0}$ & $\mathbf{7 0}$ \\
\hline
\end{tabular}

Sumber: Kep Men BUMN Nomer.100/MBU/2002.

\section{Penilaian Tingkat Kesehatan Perusahaan}

Berdasarkan Keputusan Menteri BUMN Nomor: 100/MBU/2002 tingkat kesehatan perusahaan dapat di ukur dengan skor yang telah di tentukan sesuai dengan pasal 3, yaitu sebagai berikut: 
1. AAA apabila total (TS) lebih besar dari 95

AA apabila $80<\mathrm{TS}<=95$

A apabila $65<\mathrm{TS}<=80$

Adalah kategori "Sehat".

2. BBB apabila $50<\mathrm{TS}<=65$

BB apabila $40<\mathrm{TS}<=50$

B apabila $30<\mathrm{TS}<=40$

Adalah kategori "Kurang Sehat".

3. CCC apabila $20<\mathrm{TS}<=30$

CC apabila $10<\mathrm{TS}<=20$

C apabila TS $<=10$

Adalah kategori "Tidak Sehat".

Karena keterbatasan biaya dan waktu, penelitian ini dibatasi pada aspek keuangan saja, sedangkan penilaian yang bersumber pada KEPMEN BUMN Nomor: 100/MBU/2002 adalah ada 3 (tiga) aspek yaitu Keuangan, Operasional dan Administrasi. Total Skor untuk Aspek Keuangan yang bersumber pada KEPMEN BUMN Nomor: 100/MBU/2002 adalah sebesar 70\% maka penilaiannya adalah sebagai berikut:

1. AAA apabila total (TS) lebih besar dari 66,5

AA apabila $56<\mathrm{TS}<=66,5$

A apabila $45,5<\mathrm{TS}<=56$

Kategori "SEHAT".

2. BBB apabila $35<\mathrm{TS}<=45,5$

BB apabila $28<\mathrm{TS}<=35$

B apabila $21<\mathrm{TS}<=28$

Kategori "KURANG SEHAT"

3. CCC apabila $14<\mathrm{TS}<=21$

CC apabila $7<\mathrm{TS}<=14$

C apabila TS $<=7$

Kategori "TIDAK SEHAT" 


\section{METODE PENELITIAN}

\section{Jenis Penelitian}

Dalam penelitian ini, penulis menggunakan jenis penelitian Deskriptif Kuantitatif yang menurut Syamsudin dan Damayanti (2011:101) adalah "suatu penelitian yang bertujuan menjelaskan fenomena yang ada dengan menggunakan angka - angka untuk mencandarkan karakteristik individu atau kelompok, tujuan dalam penelitian ini dibatasi yaitu untuk mengambarkan karakteristik sesuatu sebagaimana adanya".

\section{Metode Pengumpulan data}

Pada penelitian ini metode pengumpulan data yang digunakan adalah dengan menggunakan cara non participant observation. Menurut Sugiono (2011:204) adalah "teknik pengumpulan data dengan cara observasi dengan proses pengumpulan data dimana peneliti tidak terlihat dan hanya sebagai pengamat independen".

\section{Metode Analisis Data}

Dalam penelitian ini metode analisis yang digunakan adalah analisis deskriptif kuantitatif yang didukung oleh analisis kualitatif, yaitu dengan perhitungan yang bersumber pada KEPMEN BUMN Nomor: 100/MBU/2002.

\section{Variabel Penelitian}

Variabel dalam penelitian ini adalah KEPMEN BUMN Nomor: 100/MBU/2002 yang terdapat pada aspek keuangannya. 
HASIL PENELITIAN DAN PEMBAHASAN

Kinerja Keuangan PT. Indoris Printingdo bersumber pada Keputusan Menteri BUMN Nomer: KEP-100/MBU/2002.

Tabel 2

Perhitungan Kinerja Keuangan PT. Indoris Printingdo

\begin{tabular}{|l|c|c|c|c|c|}
\hline \multicolumn{3}{|c|}{ Rasio/Satuan } & 2013 & 2014 & 2015 \\
\hline \multirow{2}{*}{ Likuiditas } & CR & $\%$ & $362 \%$ & $238 \%$ & $205 \%$ \\
\cline { 2 - 6 } & CSR & $\%$ & $3,21 \%$ & $80,50 \%$ & $34,81 \%$ \\
\hline Solvabilitas & TMS & $\%$ & $12,17 \%$ & $1,31 \%$ & $0,7 \%$ \\
\hline \multirow{3}{*}{ Aktivitas } & CP & Hari & 104 hari & 61 hari & 69 hari \\
\cline { 2 - 6 } & PP & Hari & 30 hari & 38 hari & 41 hari \\
\cline { 2 - 6 } & TATO & $\%$ & $206,8 \%$ & $224,2 \%$ & $249,2 \%$ \\
\hline \multirow{2}{*}{ Profitabilitas } & ROE & $\%$ & $2,52 \%$ & $3,33 \%$ & $16,68 \%$ \\
\cline { 2 - 6 } & ROI & $\%$ & $24,47 \%$ & $1,24 \%$ & $15,16 \%$ \\
\hline
\end{tabular}

Sumber: Data Olahan, 2017

Keterangan:

Sesuai dengan KEPMEN BUMN Nomor: 100/MBU/2002 bahwa standar current ratio adalah $90 \%$ - $125 \%$, ini berarti bahwa utuk CR yang dihasilkan oleh PT. Indoris Printingdo dari tahun 2013 - 2015 adalah 362\%, 238\%, 205\% menunjukan dalam keadaan : "SEHAT".

Jika dilihat dari KEPMEN BUMN Nomor: 100/MBU/2002 bahwa standar cash ratio (CSR) adalah sebesar 0\%-35\% ini berarti PT. Indoris Printingdo dalam keadaan :"SEHAT". Tahun 2014 Cash Ratio nya 80,50\% PT. Indoris Printingdo dalam keadaan :"SEHAT" dan tahun 2015 Cash Ratio nya 34,81\% PT. Indoris Printingdo dalam keadaan :"SEHAT” meskipun nilai dari Cash Ratio-nya mengalami fluktuatif.

Jika dilihat dari KEPMEN BUMN Nomor: 100/MBU/2002 bahwa standar TMS (Total Modal Sendiri) terhadap TA (Total Aset) adalah sebesar 0\%100\%, ini berarti PT. Indoris Printingdo dalam keadaan :"SEHAT" dan tahun 2015 Rasio TMS terhadap TA sebesar $0,70 \%$ ini berarti bahwa perusahaan dalam operasionalnya aktiva sebagian besar dibiayai oleh modal sendiri, jika dilihat dari KEPMEN BUMN Nomor: 100/MBU/2002 TMS terhadap TA sebesar 0\%-100\% ini berarti PT. Indoris Printingdo dalam keadaan :"SEHAT". 
Dilihat dari KEPMEN BUMN Nomor: 100/MBU/2002 bahwa standar $C P$ (Collection Periode) sebesar 0 hari - 60 hari, ini menunjukan PT. Indoris Printingdo dalam keadaan: “TIDAK SEHAT”, tahun 2014 Rasio Collection periode sebesar 61 hari ini berarti piutang usaha berputar dalam setahun rata rata selama 61 hari dan pelunasan piutang usaha rata - rata selama 61hari, dilihat dari KEPMEN BUMN Nomor: 100/MBU/2002 bahwa standar CP sebesar 0 hari - 60 hari ini menunjukan PT. Indoris Printingdo dalam keadaan: "KURANG SEHAT" dan tahun 2015 Rasio Collection periode sebesar 69 hari ini berarti piutang usaha berputar dalam setahun rata - rata selama 69 hari dan pelunasan piutang usaha rata - rata selama 69 hari, dilihat dari KEPMEN BUMN Nomor: 100/MBU/2002 bahwa standar CP sebesar 0 hari - 60 hari, ini menunjukan PT. Indoris Printingdo dalam keadaan: "KURANG SEHAT".

Dilihat dari KEPMEN BUMN Nomor: 100/MBU/2002 bahwa standar nya PP (Perputaran Persediaan) sebesar 60 hari - 300 hari, ini menunjukan PT. Indoris Printingdo dalam keadaan : "SEHAT", pada tahun 2014 sebesar 38 hari, ini berarti persediaan barang dagang berputar (dijual dan diganti dalam satu tahun 38 hari) dilihat dari KEPMEN BUMN Nomor: 100/MBU/2002 bahwa standar nya sebesar 60 hari - 300 hari, ini menunjukan PT. Indoris Printingdo dalam keadaan : "SEHAT" dan pada tahun 2015 sebesar 41 hari, ini berarti persediaan barang dagang berputar (dijual dan diganti dalam satu tahun 41 hari) dilihat dari KEPMEN BUMN Nomor: 100/MBU/2002 bahwa standar nya sebesar 60 hari - 300 hari, ini menunjukan PT. Indoris Printingdo dalam keadaan : "SEHAT".

Dilihat dari KEPMEN BUMN Nomor: 100/MBU/2002 bahwa standar TATO nya sebesar $20 \%$ - > $200 \%$ ini menunjukan PT. Indoris Printingdo dalam keadaan : "SEHAT", pada tahun 2014 sebesar 224,20\% ini berarti perusahaan dalam menciptakan penjualan sangat efektif dalam penggunaan aktivanya, dilihat dari KEPMEN BUMN Nomor: 100/MBU/2002 bahwa standar nya sebesar $20 \%$ - > $200 \%$, ini menunjukan PT. Indoris Printingdo dalam keadaan : "SEHAT" dan pada tahun 2015 sebesar 249,20\%, ini berarti perusahaan dalam menciptakan penjualan sangat efektif dalam penggunaan 
aktivanya, dilihat dari KEPMEN BUMN Nomor: 100/MBU/2002 bahwa standar nya sebesar $20 \%$ - > $200 \%$, ini menunjukan PT. Indoris Printingdo dalam keadaan : "SEHAT".

Jika dilihat dari KEPMEN BUMN Nomor: 100/MBU/2002 bahwa standar ROE sebesar 0\% - > 15\%, ini menunjukan PT. Indoris Printingdo masih dalam keadaan :"SEHAT", tahun 2014 sebesar 3,33\%, ini berarti total laba yang dihasilkan sebesar 3,33\% nya adalah dengan menggunakan modal sendiri, jika dilihat dari KEPMEN BUMN Nomor: 100/MBU/2002 bahwa standar rasionya sebesar 0\% - > 15\%, ini menunjukan PT. Indoris Printingdo masih dalam keadaan :"SEHAT" dan di tahun 2015 sebesar 16,68\%, ini berarti total laba yang dihasilkan sebesar $16,68 \%$ nya adalah dengan menggunakan modal sendiri, jika dilihat dari KEPMEN BUMN Nomor: 100/MBU/2002 bahwa standar rasionya sebesar 0\% - > 15\%, ini menunjukan PT. Indoris Printingdo dalam keadaan :"SEHAT".

Jika dilihat dari KEPMEN BUMN Nomor: 100/MBU/2002 bahwa standar ROI sebesar 0\% - > 18\%, ini menunjukan PT. Indoris Printingdo dalam keadaan : "SEHAT", pada tahun 2014 sebesar 1,24\% ini menunjukan dengan menggunakan Rp. 1,- aktiva dapat menghasilkan laba bersih sebesar Rp.1,24,atau menunjukan perusahaan mampu menghasilkan laba dari aktiva yang digunakan sebesar $1,24 \%$ jika dilihat dari KEPMEN BUMN Nomor: 100/MBU/2002 bahwa standar rasionya sebesar 0\% - > 18\%, ini menunjukan PT. Indoris Printingdo dalam keadaan : "SEHAT" dan pada tahun 2015 sebesar $15,16 \%$, ini menunjukan dengan menggunakan Rp. 1,- aktiva dapat menghasilkan laba bersih sebesar Rp. 15,16,- atau menunjukan bahwa perusahaan mampu menghasilkan laba dari aktiva yang digunakan sebesar 15,16\%, jika dilihat dari KEPMEN BUMN Nomor: 100/MBU/2002 bahwa standar rasionya sebesar $0 \%$ - > 18\%, ini menunjukan PT. Indoris Printingdo dalam keadaan : "SEHAT". 


\section{KESIMPULAN}

Kesimpulan yang dapat diambil dari hasil penelitian dan pembahasan ini adalah sebagai berikut:

Kinerja keuangan PT. Indoris Printingdo yang bersumber pada KEPMEN BUMN Nomer: 100/MBU/2002 di tahun 2013 mendapatkan predikat "SEHAT A", ditahun 2014 mendapatkan predikat "KURANG SEHAT BBB" dan ditahun 2015 perusahaan mendapatkan predikat "SEHAT AA". Ini menunjukan kinerja keuangan PT. Indoris Printingdo masih dalam kategori baik atau mengalami trend meningkat.

\section{REFERENSI}

Andri Feriyanto dan Endang Shyta Triana. 2015. Pengantar Manajemen. Kebumen: Mediatera.

Arthur J Keown, John D Martin, J William Petty and David P Scott, JR. 2005. Financial Management: Priciples and Aplications.

Bambang, Riyanto. 2001. Dasar - Dasar Pembelanjaan Perusahaan. Edisi ke empat. cetakan ke tujuh. Yogyakarta .

Bateman, Thomas S dan Scott A. Snell. 2008. Management. Edisi 7. Jakarta : Salemba 4.

Fahmi, Irham. 2013. Pengantar Manjemen Keuangan Teori dan Soal jawaban. cetakan kedua. Bandung: Alfabeta.

KEPMEN BUMN No. KEP-100/MBU/2002, Tentang Penilaian Tingkat Kesehatan Perusahaan.

Mahmudi. 2007. Manajemen Kinerja Sektor Publik. UPP STIM YKPN.

Mulyadi. 2001. Alat Manajemen Kontemporer Untuk Pelipat gandaan Kinerja Keuangan Perusahaan. Salemba Empat.

Munawir, S.2013. Analisis Informasi Keuangan, Liberty, Yogyakarta.

Robins, Stephen P. Dan Coulter, Mary. 2008. Manajemen.Jakarta: PT. Indeks Sugiyono. 2011. Metode Penelitian Kuantitatif, Kualitatif dan $R \& D$. Alfabeta. 
Suwatno. Dan Priansa, D. 2011. Manajemen SDM dalam organisasi publik dan bisnis. Bandung: Alfabeta.

Suyadi Prawirosentono. 2008.Manajemen Sumber Daya Manusia Kebijakan Kinerja Karyawan. Yogyakarta: BPFE.

Syamsudin dan Damayanti. 2011. Metode Penelitian Pendidikan Bahasa. Bandung: Remaja Rosdakarya. 